\title{
Synthesis and Evaluation of Antibacterial Potency of Silver Nanoparticles of Extracts of Ziziphus mauritina and Coriandrum sativum
}

Pallav Kaushik Deshpande ${ }^{1 *}$, Gopeshvari Sahu ${ }^{2}$, Ragini Gothalwal ${ }^{1}$

${ }^{1}$ Department of Biotechnology, Barkatullah University, Bhopal (MP)
${ }^{2}$ Department of Biotechnology, Govt.V.Y.T. Post Graduate Autonomous College, Durg (C.G)

Article History

Received: 12.10 .2020

Accepted: 27.10 .2020

Published: 30.10 .2020

Journal homepage:

https://www.easpublisher.com/easjbg

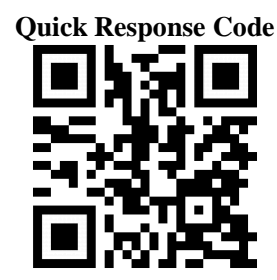

Abstract: The major advantage of using plant extracts for silver nanoparticle synthesis is that they are easily available, safe, and nontoxic in most cases, have a broad variety of metabolites that can aid in the reduction of silver ions, and are quicker than microbes in the synthesis. The main mechanism considered for the process is plant-assisted reduction due to phytochemicals. In present we had selected two plant - Ziziphus mauritina commonly known as Indian jujube (Ber) and Coriandrum sativum commonly known as coriander for the phytochemical screening, nanoparticle synthesis and antibacterial activity against Kliebsella pneumonia, Clostridium per fringes, Citrobacter freundii and Staphylococcus aureus bacteria. All the bacteria selected in this study are highly and drug resistant. Potency of these plant extract against selected bacterial culture increases with formulation of nanoparticles. When compared with free extract in terms of zone of inhibition exhibited by bacterial culture. Zeta potential analysis of nanoparticles confirms that all the nanoparticles are of size loss them $100 \mathrm{~nm}$. Stability of nanoparticles up to 15 days was observed which confirms the method of preparation of nanoparticle is stable and successful. Research finding confirms the format and stable nature of nanoparticles, which make them, potential and significant in drug delivery agent.

Keywords: Silver nanoparticles, Ziziphus mauritina, Coriandrum sativum, anti-bacterial, potency.

Copyright (C) 2020 The Author(s): This is an open-access article distributed under the terms of the Creative Commons Attribution 4.0 International License (CC BY-NC 4.0) which permits unrestricted use, distribution, and reproduction in any medium for non-commercial use provided the original author and source are credited.

\section{INTRODUCTION}

For nanoparticles preparation three major types of reactions involves - physical, chemical and biological. Silver nanoparticles have attracted much attention because their properties for utilizing in different application inclusive pharmaceutics, agriculture, water detoxification, Air filtration, textile industries and as an activated in oxidization reaction [1]. Nanoparticles can be synthesized by non-biological and biological methods. Among non-biological methods, they can be synthesized by physical and chemical methods. But main disadvantages of using these methods are that they are expensive and cause release of hazardous chemicals. Due to this, many researchers move towards the biological method of synthesis. In this, many bacteria, fungi, plant extracts, yeasts and biological particles have been exploited for nanoparticle synthesis. Silver nanoparticles can be synthesized extracellulary or intracellularly by these biological agents [2].

The main phytochemicals involved are terpenoids, flavones, ketones, aldehydes, amides, and carboxylic acids. Flavones, organic acids, and quinones are water-soluble phytochemicals that are responsible for the immediate reduction of the ions.
Studies have revealed that xerophytes contain emodin, an anthraquinone that undergoes tautomerization, leading to the formation of the silver nanoparticles.

The antimicrobial effects of leaf extract of these three medicinal plants and their respective biologically synthesized Ag NPs was evaluated by disc diffusion method. Comparative studies were also performed to analyze the toxicity of these biologically synthesized Ag NPs on three legume plants of the coriandrum (Coriandrum sativa), and ber (Ziziphus mauritiana) as they are native to the Indian Subcontinent and widely consumed.

\section{MATERIAL AND METHOD \\ Maintenance of bacterial culture}

Pure culture of Keliebsell pneumonia, Staphococus aures, Closridium perfiuges and citrobactear freundii were obtained from Department of Biotechnology of Barkatullah university from slants and pure culture were maintained though out the dissertation work through sub culturing, fresh slants were also prepared for storage of pure culture. 


\section{Well Diffusion Method}

For In vitro antibacterial screening agar plates were made, then the bacteria culture are poured and with the help of a spreader inoculum were spreaded on petriplates. After that small holes were punctured on the agar plates. In those wells extracts (both ethanol and aqueous) of different dilution series ranging from $10 \mu \mathrm{l}-$ $100 \mu 1$ were poured with the help of a micropipette and these plates were kept in the incubator for 24 hours at $37^{\circ} \mathrm{C}$. After incubation the growth of the bacteria is noted. The area near the well shows no growth that is called the zone of inhibition which means that the phytoconstituents present in the extract have the potency to inhibit the growth of the bacterial strains. The zone of inhibition is calculated with the formula $\pi r^{2}$ (these experiments were also done in triplicate). All the test were conducted is triplicates, Cappuccino and Sherman [3].

\section{Plant Collection and Extraction}

Ziziphus maritain leaves were collected from various regions of campus of Barkatullah university Bhopal. Each sample was tagged and placed in separate zip lock polythene bags, brought back to the lab and processes collection. These plant samples were washed in running tap water for 15 minutes. The Coriander sativum plant procured from the local market.

The collected plants were washed with tap water and kept in room temperature for dry. After the plant dries, the leaves and stems of the plant are made by cutting the plant or cutting it into small pieces or with the help of, scissors or knives. The plant extracts were obtained by putting the air dried and crushed leaves in a soxillate extraction machine. The extraction was made using alcohol and distilled water.

\section{Soxhlet Extraction}

In conventional soxhlet, the sample in this case plant leaves of Indian jujube and leaves and leaf of coriander and giloy was washed, dried and crushed then placed in a thimble-holder and during operation is gradually filled with condensed fresh solvent (Ethanol and water ) from a distillation flask. When the liquid reaches an overflow level, a siphon aspirates the whole contents of the thimble-holder and unloads it back into the distillation flask, carrying the extracted analytes in the bulk liquid. This operation is repeated until complete extraction is achieved after six rounds of soxhlet cycle. After the completion extraction process the collected extract was dried at $50^{\circ} \mathrm{C}$ to achiev to achieve the desired consistency required for future use, extracted material was then stored in air tight container [4].

\section{Yield of extract}

After extraction, each cycle was analysed for $\%$ yield of the extract is calculated in percentage by the formula $\%$ Yield $=w t$. of the extract/ wt. of the plant material× 100

\section{Phytochemical analysis}

The commonly known phytochemicals from Coriander sativum, Ziziphus mauritina are cardiac glycosides, terpenoids, steroids, saponin, tannin, flavonoids and alkaloids. Extracts were subjected to various chemical tests in order to determine the secondary plant constitutuents present by employing standard procedures as follows. (All the tests weredone in triplicates) [4].

\section{Total ash}

Presence of ash in any drug (natural) is a limited factor which can interfere with the pharmacological properties of extract. During validation and formulation ash value must be in lower rang, lower the value higher the potency of the extract. To determine total ash about 2 of the air-dried extract was placed in a crucible, extract was then spread in an even layer and ignited and gradually the temperature was increased to $450^{\circ} \mathrm{C}$ until it is white, indicating the absence of carbon. The content was cooled in a desiccator and weighed. Ash value can be calculated by using formul: - Ash value = Initial Weight - final Weight $\times 100 /$ Intial weight Uprieti et al. [5].

\section{Water soluble ash}

The total ash obtained from $2 \mathrm{~g}$ extract was boiled with $25 \mathrm{ml}$ of distilled water for 5 minutes. The insoluble matter was collected on an ash less filterpaper, washed with hot water and ignited to constant at low temperature. The weight of the insoluble matter was subtracted from the weight at total ash, represent the water soluble ash. The percentage of water soluble ash was calculated with reference to the air dried drug Uprieti et al., [5].

\section{Test for cardiac glycosides}

Test for Cardiac Glycosides $0.5 \mathrm{ml}$ of each extract was treated with $0.2 \mathrm{ml}$ glacial acetic acid then 1 drop of $3.5 \%$ ferric chloride $\left(\mathrm{FeCl}_{3}\right)$ was added to the solution. This was layered with $1 \mathrm{ml}$ of concentrated $\mathrm{H}_{2} \mathrm{SO}_{4}$. A reddish brown ring was occurred at the interface indicates the presence of cardiac glycosides.

\section{Test for terpenoids}

$0.5 \mathrm{ml}$ of plant extract was added to the test tube then $2 \mathrm{ml}$ of chloroform was mixed to the solution. $3 \mathrm{ml}$ of concentrated ${ }_{1}$ was added carefully from the wall of the test tube, to form a lower layer. Occurrence of reddish-brown colour at the interface indicated the presence of terpenoids.

\section{Test for steroids}

Test for Steroid $0.5 \mathrm{ml}$ of extract was dissolved in $3 \mathrm{ml}$ of chloroform. The solution was filtered, $2 \mathrm{ml}$ of concentrated $\mathrm{H}_{2} \mathrm{SO}_{4}$ wasadded to the filtrate to form a lower layer. A reddish-brown colour ring at the interface was indicated the presence of steroid. 


\section{Test for aponin}

Test for Saponin $0.5 \mathrm{ml}$ of extract was taken in the test tube, and then $5 \mathrm{ml}$ of distilled water was added to it. The solution was vigorously shaken and stable persistent froth was observed for the presence of saponin.

\section{Test for tannin}

Test for Tannin $0.5 \mathrm{ml}$ of extract and $5 \mathrm{ml}$ of distilled water was taken in test tube then it was boiled then filtered. Few drops of concentrated $\mathrm{H}_{2} \mathrm{SO}_{4}$ and $1 \%$ $\mathrm{FeCl}_{3}$ were added to the filtrate. Deep green, brownish green or blue black coloration was indicated the presence of tannin.

\section{Test for flavonoid}

Test for Flavonoid $0.5 \mathrm{ml}$ of extract and $5 \mathrm{ml}$ distilled water was added to test tube then it was filtered. $5 \mathrm{ml}$ of diluted ammonia solution was added to the filtrate then concentrated $\mathrm{H}_{2} \mathrm{SO}_{4}$ was added. A yellow coloration indicated the presence of flavonoid. The yellow color disappeared on standing.

\section{Test for alkaloids}

Test for Alkaloid $0.5 \mathrm{ml}$ dried extract was taken and $3 \mathrm{ml}$ of methanol was added to it. Then $300 \mu \mathrm{l}$ of acetic acid (10\% of methanol) was added to the solution ammonium hydroxide was added drop wise. Appearance of precipitate indicated the presence of alkaloid.

\section{Biosynthesis of nanoparticles and antibacterial activity}

Aqueous solution of silver nitrate $(1 \mathrm{mM})$ was prepared and mixed with fresh plant extract of Coriander sativum and Ziziphus mauritina at a ratio of $8: 2$. This solution was placed on a shaker with magnetic stirrer in the room temperature at $27 \pm 2^{\circ} \mathrm{C}$ for $24 \mathrm{~h}$. All stages of the experiment were implemented in three replicates. Silver nanoparticles synthesized by plant extract were tested for antibacterial activity agar well diffusion method against pathogenic bacteria.

\section{Well diffusion assay}

In this method $20 \mu \mathrm{l}$ bacterial cultures were seeded on the surface of Nutrient Agar Media plates by spread plate technique. Media was punched with a sterile cork borer to make open wells $(4 \mathrm{~mm})$ in all plates. Different colloidal solutions of silver nanoparticles $(2 \mu \mathrm{l}, 4 \mu \mathrm{l}, 6 \mu \mathrm{l}$ and $8 \mu \mathrm{l})$ synthesized above were poured in separate wells. Then these plates were incubated at $37^{\circ} \mathrm{C}$ for 24 hrs. After 24 hours incubation antibacterial activities of different nanoparticles sample were recorded in terms of diameter of inhibition zone measured in $\mathrm{mm}$ by using scale.

\section{Characterization of silver nanoparticles}

The brown colloidal solution containing silver nanoparticles obtained in above experiments is further subjected to following characterization techniques for determination of their physical, chemical properties viz., size, stability etc.

\section{UV-Visible spectroscopic analysis}

Change in colour of the mycelium free water extract incubated with $1 \mathrm{~mm}$ silver nitrate solution visually observed over a period of time indicates the bio reduction of silver ions to silver nanoparticles. The colloidal brown solution was monitored by absorption measurements carried out on UV-Visible Spectrophotometer (UV 1800 spectrophotometer Schimadzu) at a resolution of $1 \mathrm{~nm}$ between 300 to 600 $\mathrm{nm}$ (which is a characteristic wavelength absorption range for silver nanoparticles) wavelength range for confirming the synthesis of silver nanoparticles in the solution [6]. For absorption measurements, different brown colloidal solutions were poured in cuvette and placed in sample holder where wavelength of specific range is passed through it and absorption values are displayed in the form a spectra. Maximum absorption at a particular wavelength was depicted as a peak .Two plant Ziziphus mauritiana and coriandraum staivum through soxhlation aqueous and ethenolic extracts were obtained.

\section{RESULTS AND DISCUSSION Yield of Extract}

The table 1 shows the \%yield of the both ethanolic as well as aqueous extract of all the three plants . The yield of extract of leaf of zizipus mauritiana was found to be more when ethanol used as a solvent $(15.9 \pm 0.77)$ as compared to when water was used as a solvent $(5.1 \pm 1.3)$.

\section{Total Ash Value}

Ash value of different extract was calculated and results of ash value are given in table 2.The total ash value of Zizipus mauritiana was calculated $0.72 \pm 0.1 \%, 1.083 \pm 0.01 \%$ for ethanolic and aqueous leaf extract respectively. For water soluble ash the values are $0.24 \pm 0.06 \%, 0.25 \pm 0.02 \%$ for ethanol and aqueous extract respectively whereas acid insoluble ash are $0.19 \pm 0.01 \%, 0.2 \pm 0.01 \%$ respectively for Coriander sativum it was $0.36 \pm 0.02 \mathrm{gm}, 0.19 \pm 0.01 \mathrm{gm}$ for the ethanol and aqueous leaf extract respectively. The water soluble ash values are $0.15 \pm 0.05 \mathrm{gm}, 0.12 \pm 0.02 \mathrm{gmfor}$ ethologic and aqueous extract respectively whereas acid insoluble ash are $0.14 \pm 0.06 \%, 0.05 \pm 0.01 \mathrm{gm}$ for ethanolic and aqueous extract respectively

\section{Phytochemical screening of extracts}

Results are shown in table 3, The present study revealed that the ethanol extract of leaf of Zizipus mauritiana has tannims (cathecolic), the aqueous extract of leaf of reducing sugar, saponin, glycoside. However, the aqueous extract of leaf of Zizipus mauritiana contained reducing sugar and saponins(table 
3). Both the extracts showed the presence of rich variety of secondary metabolites. Glycosides are present in ethanolic extract while absent in aqueous. ethanolic extract of plant of Coriandrum sativum contains, tannins (cathecolic), and saponins, However, the aqueous extract contains only saponins.

\section{Biosynthesis of silver nanoparticles}

Aqueous solution of silver nitrate $(1 \mathrm{mM})$ was prepared and mixed with fresh plant extract of Coriander sativum, Ziziphus mauritina and Tinospora cordifoliaat a ratio of 8:2. This solution was placed on a shaker with magnetic stirrer in the room temperature at $27 \pm 2{ }^{\circ} \mathrm{C}$ for $24 \mathrm{~h}$. All stages of the experiment were implemented in three replicates.

\section{Screening of antibacterial activity}

The in vitro antibacterial activities of ethanol extract of $Z$. mauritiana is given in the table4. In one of the previous study (Deshpande et al, 2020) free plant extract fails to inhibit the growth with of Kliebsella pneumonia but, nanoparticles preparation is effective against Kliebsella pneumonia population. It is evident from the results that the nanoparticles inhibit two population of Clostridium perfringes $0.5 \mathrm{~cm}^{2}, 1.54 \mathrm{~cm}^{2}$, $1.13 \mathrm{~cm}^{2}, 4.52 \mathrm{~cm}^{2}$ and Staphlococcus aureus $2.01 \mathrm{~cm}^{2}$, $2.54 \mathrm{~cm}^{2}, 1.54 \mathrm{~cm}^{2}, 3.80 \mathrm{~cm}^{2}$. More effective compared to free extract while nanoparticles inhibit population of Citrobacter freundii while free plant extract fails inhibit do the population and area is $0.50 \mathrm{~cm}^{2}, 0.78 \mathrm{~cm}^{2}$, $1.13 \mathrm{~cm}^{2}, 1.54 \mathrm{~cm}^{2}$.

The table 5 shows the yield $\%$ of ethanolic and aqueous extract of plant (coriandrum sativum) using aqueous and ethanolic solvent. The yield of extract of the plant of Coriandrum sativum found to be more when water was used as a solvent $(18.0 \pm 5.0 \%)$ as compared to when ethanol was as a Solvent $(7.09 \pm 4.0 \%)$. Kliebsella pneumonia was not affected by nanoparticle of Ziziphus mauritiana even at higher concentration. Organism like Citrobacter freundii and Clostridium perfringes shows no inhibition when exposed to free extract of Coriandrum sativum plant while when treated with nanoparticles $8 \mu \mathrm{l}$ Kliebsella pneumonia, Staphylococcus aureus Citrobacter freundii and Clostridium perfringes zone of inhibition was observed as $1.3 \mathrm{~cm} 2,0.7 \mathrm{~cm}^{2}, 0.9 \mathrm{~cm}^{2}, 1.1 \mathrm{~cm}^{2}$. In one of the our previous study free plant extract do not inhibit the growth of Clostridium perfringes even nanoparticles preparation also stop Clostridium perfringes $1.13 \mathrm{~cm}^{2}, 1.54 \mathrm{~cm}^{2}, 2.01 \mathrm{~cm}^{2}, 2.54 \mathrm{~cm}^{2}$ area population. The zone of inhibition of Kliebsella pneumonia $3.8 \mathrm{~cm}^{2}, 3.8 \mathrm{~cm}^{2}, 4.52 \mathrm{~cm}^{2}, 5.31 \mathrm{~cm}^{2}$ area. It is evident from the results that the nanoparticles inhibit two population of and Staphylococcus aureus $0.78, \mathrm{~cm}^{2}$
$0.78 \mathrm{~cm}^{2} 1.13 \mathrm{~cm}^{2}, 1.54 \mathrm{~cm}^{2}$ more effective compared to free extract While nanoparticles inhibit population of Clostridium perfringes while free plant extract not inhibit do the population and area is $1.54 \mathrm{~cm}^{2}, 0.78 \mathrm{~cm}^{2}$, $5.31 \mathrm{~cm}^{2}, 4.52 \mathrm{~cm}^{2}$ area.

\section{Nanoparticle prepration}

The fresh extract of Coriandrum sativum and Ziziphus mauritiana, was yellow in color, but after addition of $\mathrm{AgNO}_{3}$ solution, $1 \mathrm{~N} \mathrm{AgNO}_{3}$ solution was prepared by mixing $10 \mathrm{ml} \mathrm{D} / \mathrm{W}$ in $0.1 \mathrm{~g} \mathrm{AgNO}_{3}$, the solution for nanoparticles prepared by mixing $16 \mathrm{ml}$ of $\mathrm{D} / \mathrm{W}$ with $3 \mathrm{ml}$ of $\mathrm{AgNO}_{3}$ and $1 \mathrm{ml}$ plant extract was added. With continuous stirring for 24hours at room temperature, gradually the color of the solution changes to red. The intensity of the color increased, which confirmed $\mathrm{Ag}$ ion reduction and the formation of $\mathrm{Ag}$ NPs. Silver nanoparticle surface plasmon excitation causes colour change in the solution, which is the primary and notable evidence for the formation of $\mathrm{Ag}$ NPs.

\section{UV-Vis analysis}

$\mathrm{UV}-\mathrm{Vis}$ absorption spectrum of $\mathrm{Ag}$ NPs is shown in Fig. Broad bell-shaped spectrum curve was obtained from UV-Vis analysis. Various metabolites from plant extract introduced to solution make the Plasmon band broad because they may be read in this spectrophotometric range, too. Surface plasmon resonance (SPR) of silver occurs at 300nm. To $600 \mathrm{~nm}$. This peak increased with time up to $360 \mathrm{~min}$. According to Mie theory, spherical nanoparticles show only a single SPR band. The number of peaks increases by increasing diversity of particles shapes. Then, it can be concluded that biosynthesized Ag NPs are unanimously spherical in nature. In present study nanoparticles of all the extract are giving $\lambda$ mean of $440-500 \mathrm{~nm}$. Nanoparticles gives $\lambda$ mean at around $460-500 \mathrm{~nm}$. Result confirms that at nanoparticles formed is present research are table and intact which is a good.

\section{Stability of nanoparticles}

The activity was determined by spectrophotometer analysis. All the nanoparticles formed give lambda mean at $380-400 \mathrm{~nm}$ up to 15 days of prepration which conferm the integrity and stablility of nanoparticles formed.

From both the result we can conclude that method which was adopted by to form nanoparticles is best suited for plant extract and stability up to 15 days is a good sign and holds future properties for plant extract nanoparticles for application use. 
Table-1: Result showing \% yield of extract

\begin{tabular}{|r|l|l|l|}
\hline S NO. & PLANT NAME & SOLVENT USED FOR EXTRACTION & YIELD OF EXTRACT (gm) \\
\hline 1. & Coriandrum sativum & ETHENOL & $15.9 \pm 0.77$ \\
\hline 2. & Coriandrum sativum & AQUEOUS & $5.1 \pm 1.3$ \\
\hline 3. & Ziziphus mauritiana & ETHANOL & $7.09 \pm 4.0$ \\
\hline 4. & Ziziphus mauritiana & AQUEOUS & $18.0 \pm 5.0$ \\
\hline
\end{tabular}

Table-2: Total cash value

\begin{tabular}{|l|l|l|l|l|l|}
\hline $\begin{array}{l}\text { S. } \\
\text { NO. }\end{array}$ & PLANT NAME & $\begin{array}{l}\text { SOLVENT USED } \\
\text { FOR EXTRACTION }\end{array}$ & $\begin{array}{l}\text { TOTAL ASH } \\
\text { VALUE }(\mathbf{g m})\end{array}$ & $\begin{array}{l}\text { WATER SOLUBLE } \\
\text { ASH }(\mathbf{g m})\end{array}$ & $\begin{array}{l}\text { ACID SOLUBLE } \\
\text { ASH(gm) }\end{array}$ \\
\hline 1 & Coriandrum sativum & ETHANOL & $0.75 \pm 0.1$ & $0.35 \pm 0.06$ & $0.20 \pm 0.01$ \\
\hline 2 & Coriandrum sativum & AQUEOUS & $1.095 \pm 0.01$ & $0.28 \pm 0.02$ & $0.3 \pm 0.01$ \\
\hline 3 & Ziziphus mauritiana & ETHANOL & $0.36 \pm 0.02$ & $0.15 \pm 0.05$ & $0.21 \pm 0.01$ \\
\hline 4 & Ziziphus mauritiana & AQUEOUS & $0.19 \pm 0.01$ & $0.12 \pm 0.02$ & $0.06 \pm 0.01$ \\
\hline
\end{tabular}

Table-3: Result of phytochemical analysis of ethanolic and aqueous extracts of zizipus mauritiana

\begin{tabular}{|c|c|c|c|c|}
\hline S.NO. & PLANT NAME & $\begin{array}{l}\text { PHYTOCHEMICAL } \\
\text { COMPOUND }\end{array}$ & $\begin{array}{l}\text { ETHANOLIC } \\
\text { EXTRACT }\end{array}$ & $\begin{array}{l}\text { AQUEOUS } \\
\text { EXTRACT }\end{array}$ \\
\hline 1 & \multirow[t]{6}{*}{ Zizipus mauritiana } & TANNINS(cathecolic) & + & - \\
\hline 2 & & VOLATILE OIL & - & - \\
\hline 3 & & REDUCING SUGAR & + & + \\
\hline 4 & & SAPONIN & + & + \\
\hline 5 & & GLYCOSIDE & + & - \\
\hline 6 & & ALKALOIDS & - & - \\
\hline 7 & \multirow{6}{*}{$\begin{array}{l}\text { Coriandrum } \\
\text { sativum }\end{array}$} & TANNINS(cathecolic) & + & - \\
\hline 8 & & VOLATILE OIL & - & - \\
\hline 9 & & REDUCIN SUGAR & - & - \\
\hline 10 & & SAPONINS & + & + \\
\hline 11 & & GLYCOSIDE & - & - \\
\hline 12 & & ALKALOID & - & - \\
\hline
\end{tabular}

$+=$ present; $-=$ absent

Table-4: Zone of inhibition of nanoparticle of ethanolic extract of Ziziphs mauritiana leaf.

\begin{tabular}{|c|c|c|c|c|c|}
\hline \multirow[t]{2}{*}{ S. No } & \multirow{2}{*}{$\begin{array}{l}\text { Dose of plant extract } \\
\text { and nanoparticles in } \mu \mathrm{l}\end{array}$} & \multicolumn{4}{|c|}{ Area of zone of inhibition in $\mathrm{cm}^{2}$} \\
\hline & & $\begin{array}{l}\text { Kliebsella } \\
\text { Pneumonia }\end{array}$ & $\begin{array}{l}\text { Staphlococcus } \\
\text { Aureus }\end{array}$ & $\begin{array}{l}\text { Citrobacter } \\
\text { Freundii }\end{array}$ & $\begin{array}{l}\text { Clostridium } \\
\text { Perfringes }\end{array}$ \\
\hline 1. & 2 & $* *$ & 0.8 & 0.4 & 0.5 \\
\hline 2 & 4 & $* *$ & 0.9 & 0.5 & 0.6 \\
\hline 3 & 6 & $* *$ & 0.7 & 0.6 & 0.7 \\
\hline 4 & 8 & $* *$ & 1.1 & 0.7 & 1.2 \\
\hline
\end{tabular}

**No zone of inhibition was observed.

\#\#results are the men value of triplicate

Table-8: Zone of inhibition of nanoparticles of ethanolic extract of Coriandrum sativum leafs

\begin{tabular}{|c|c|c|c|c|c|}
\hline \multirow[b]{2}{*}{$\begin{array}{l}\text { S. } \\
\text { NO }\end{array}$} & \multirow[b]{2}{*}{$\begin{array}{l}\text { DOSE OF EXTRACT } \\
\text { IN }(\mu \mathrm{l})\end{array}$} & \multicolumn{4}{|c|}{ Area of zone of inhibition in $\left(\mathrm{cm}^{2}\right)$} \\
\hline & & $\begin{array}{l}\text { Kliebsella } \\
\text { pneumonia }\end{array}$ & $\begin{array}{l}\text { Staphylococcus } \\
\text { aureus }\end{array}$ & $\begin{array}{l}\text { Citrobacter } \\
\text { freundii }\end{array}$ & $\begin{array}{l}\text { Clostridium } \\
\text { perfringes }\end{array}$ \\
\hline 1 & 2 & 1.1 & 0.5 & 0.6 & 0.7 \\
\hline 2 & 4 & 1.1 & 0.5 & 0.7 & 0.5 \\
\hline 3 & 6 & 1.2 & 0.6 & 0.8 & 1.2 \\
\hline 4 & 8 & 1.3 & 0.7 & 0.9 & 1.1 \\
\hline
\end{tabular}

\#\# Results are the mean value of triplicate. 


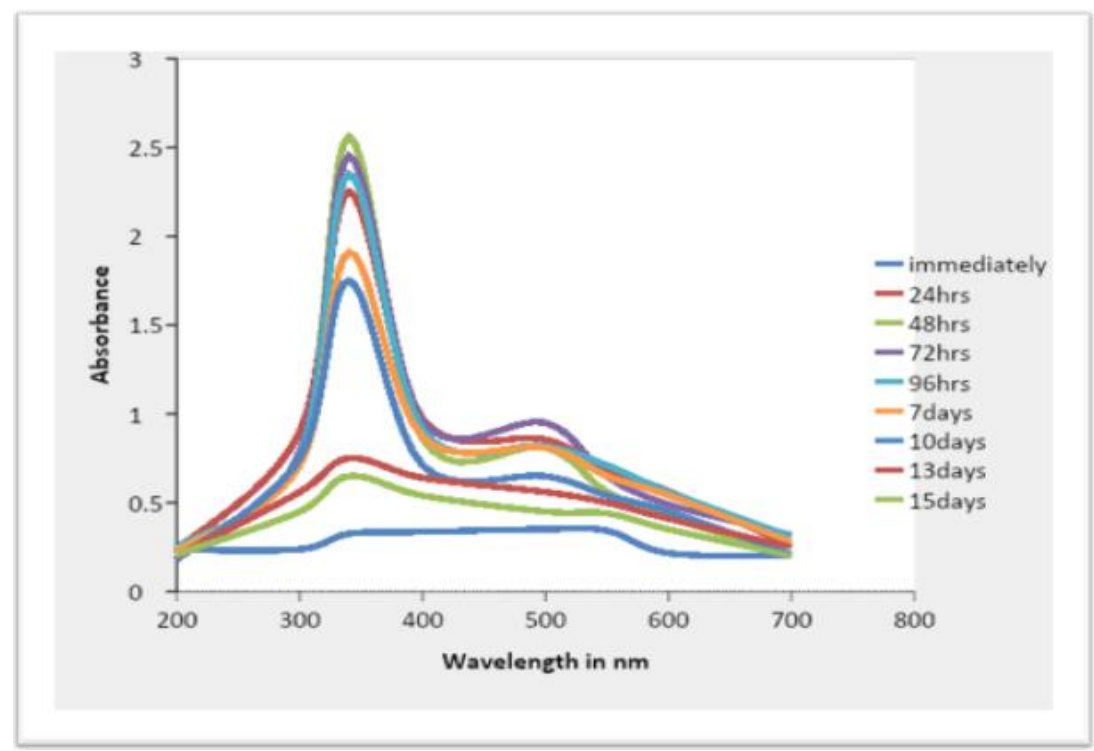

Fig-1: Graph showing the activity of nanoparticles (15 days)

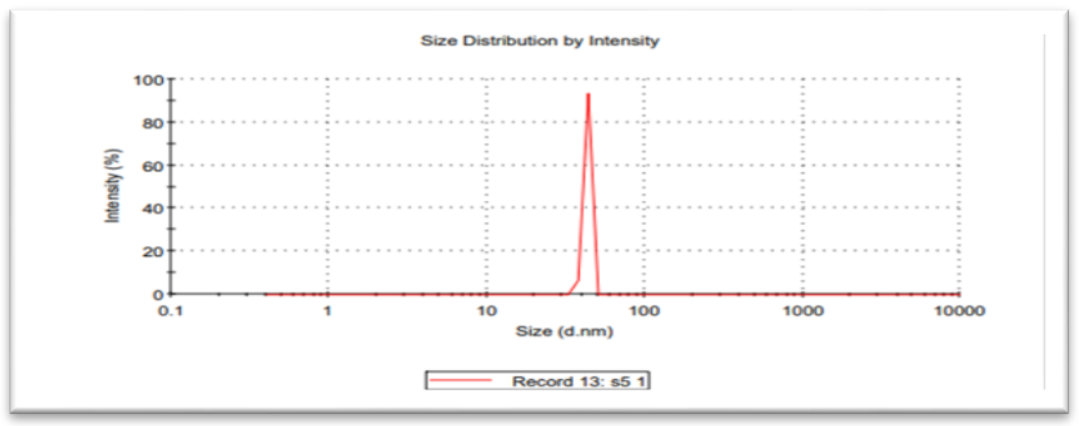

Fig-2: Zeta potential analysis

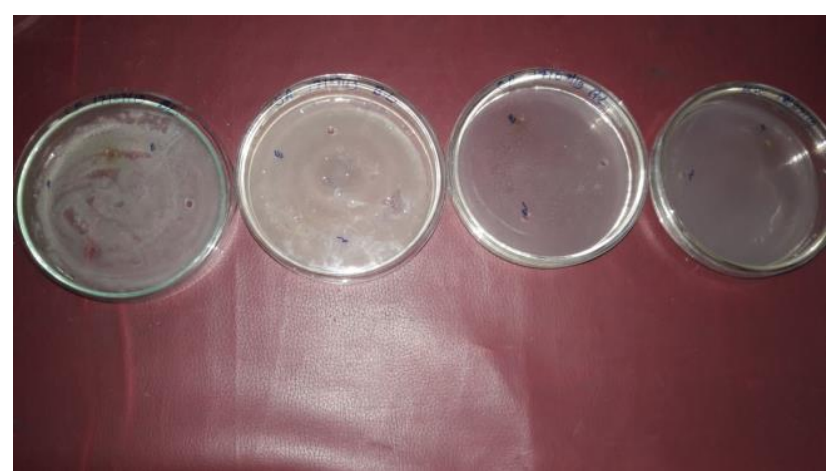

Fig-3: Agar plates showing susceptibility of Clostridium perfringes, Citrobacter freungii, kliebsella pneumonia and staphylococcus aureus through zone of inhibition against ethanolic extract of Ziziphus mauritiana

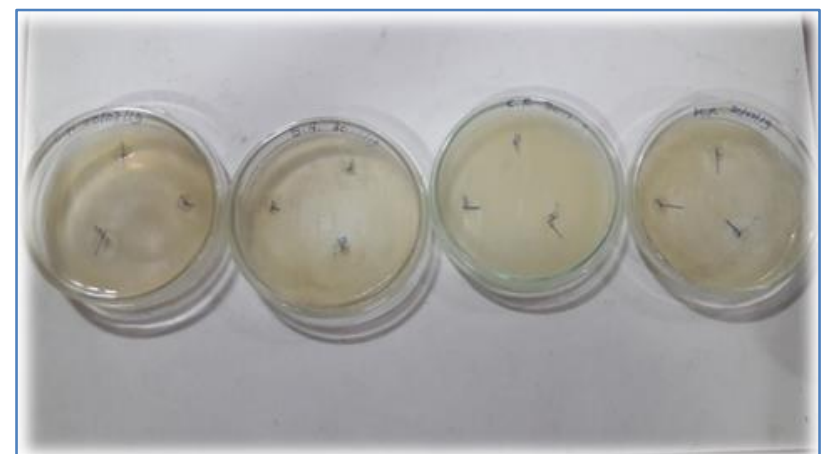

Fig-4: Agar plates showing susceptibility of Clostridium perfringes, Citrobacter freungii, kliebsella pneumonia and staphylococcus aureus through zone of inhibition against ethanolic extract ofCoriandrum sativum 

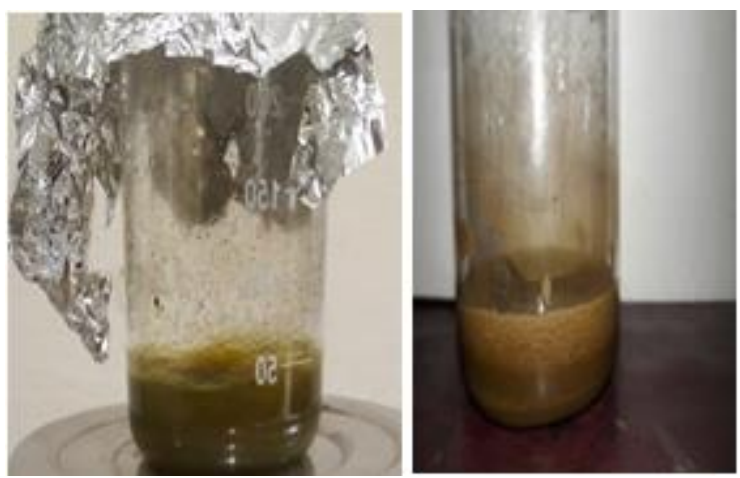

Fig-5: (A): Plant extract with $\mathrm{AgNO}_{3}$ (B) after 24h in magnetic stirrer

\section{CONCLUSION}

Bactericidal activity assessment of the biosynthesized Ag NPs showed their inhibitory function against both Gram-positive and Gram-negative bacteria. Zeta potential analysis of nanoparticles confirms that all the nanoparticles are of size loss them $100 \mathrm{~nm}$. Stability of nanoparticles up to 15 days was observed which confirms the method of preparation of nanoparticle is stable and successful. Organism like Citrobacter freundii shows no inhibition when exposed to free extract but, zone of inhibition was recorded when exposed to Nanoparticle $0.7 \mathrm{~cm}^{2}$.

\section{FUTURE RECOMMENDATION}

In place of crude extract purified extract like (tannins, saponins, flavonoid, glycosides etc.) can lead to a potent drug discovery. These plants can be further exploited as potent alternative to current drug therapy against bacterial infection. Nanoparticle of purified plant extract can be exploited in future which will definitely leads to positive outcomes.

\section{REFERENCES}

1. Pirtarighat, S., Ghannadnia, M., \& Baghshahi, S. (2019). Green synthesis of silver nanoparticles using the plant extract of Salvia spinosa grown in vitro and their antibacterial activity assessment. $J$ Nanostruct Chem, 9, 1-9.

2. Rahi, D.K., \& Parmar, A.S., \& Tiwari, V. (2014). Biosynthesis of silver nanoparticles from fungal root endophytes of Sida acuta plant and evaluation of their antibacterial and antibiotic enhancing activity. International Journal of Pharmacy and Pharmaceutical Sciences, 6. 160-166.

3. Cappucino, J., Sherman, N. (2006). Microbiology: A Laboratory Manual 6th edition. Dorling Kindersley (India) Pvt. Ltd.

4. Kokate, C.K. (2005). A text book of practical Pharmacognosy. Val. Prakashan, 5:105-111.

5. Upreti, K., Semwal, A., Upadhyaya, K., Masiwal, M. (2013). Pharmacognostical and Phytochemical Screening of Leaf Extract of Zanthoxylum armatum DC. International Journal of Herbal Medicine, 1(1) : 6-11

6. Devi, L. S., \& Joshi, S. R. (2015). Ultrastructures of silver nanoparticles biosynthesized using endophytic fungi. Journal of Microscopy and Ultrastructure, 3(1), 29-37. 